\title{
Ingestion of fluorescently labeled and phycoerythrin-containing prey by mixotrophic dinoflagellates
}

\author{
Aishao Li ${ }^{1, *}$, Diane K. Stoecker ${ }^{1}$, D. Wayne Coats ${ }^{2}$, E. Jeremy Adam ${ }^{2}$ \\ ${ }^{1}$ University of Maryland System, Center for Environmental and Estuarine Studies, Horn Point Environmental Laboratory, \\ Cambridge, Maryland 21613, USA \\ ${ }^{2}$ Smithsonian Environmental Research Center, Box 28, Edgewater, Maryland 21037, USA
}

\begin{abstract}
In order to experimentally investigate feeding by mixotrophic dinoflagellates, we developed protocols for the use of live protistan prey as markers of ingestion. CMFDA (5-chloromethylfluorescein diacetate), a vital green fluorescent stain, was used to label cultures of photosynthetic nanoflagellates, a diatom, and an oligotrichous ciliate. Cryptophytes were not readily stained with CMFDA, but phycoerythrin-containing members of this phylum have a distinct yellow-orange fluorescence and thus can be used unstained to demonstrate ingestion. With these complementary techniques, we qualitatively demonstrated feeding by the dinoflagellates Ceratium furca, Gymnodinium sanguineum, Gyrodinium estuariale, Prorocentrum minimum (= mariae-lebouriae) and Peridinium brevipes in natural asscmblages from Chesapeake Bay, USA. We also used CMFDA-stained Isochrysis galbana (Prymnesiophyta) and unstained Cryptomonas sp. (Cryptophyta) in laboratory and field studies, respectively, to examine prevalence of feeding by $G$. estuariale as a function of prey density However, determination of in situ grazing rates for mixotrophic dinoflagellates proved difficult, as only a small percentage of cells contained labeled food vacuoles following short incubations $(\leq 4 \mathrm{~h})$ with stained prey added at tracer concentrations. The use of CMFDA-stained cells and phycoerythrincontaining prey as markers of ingestion should also be applicable to species-specific feeding studies with other phagotrophic protists and micro-metazoa. The protocols prescnted here have advantages over the use of fluorescent microspheres or fluorescently labeled heat-killed algae (FLA) for investigating grazing or predation because many micrograzers do not readıly ingest, or discriminate against. inert particles.
\end{abstract}

KEY WORDS: Chesapeake Bay Ciliates C CMFDA-labeled protists · Cryptophytes Dinoflagellates . Grazing $\cdot$ Mixotrophy

\section{INTRODUCTION}

Mixotrophy, used here for species that combine phototrophy and phagotrophy, appears to be common among the dinoflagellates (reviewed in Schnepf \& Elbrächter 1992); however, few studies have quantified feeding by photosynthetic members of this phylum. In a laboratory experiment, Porter (1988) found that the freshwater dinoflagellate Peridinium inconspicuum ingested polystyrene beads at a rate of 0.40 beads

\footnotetext{
•E-mail: aishao@hpel.cees.edu
}

cell ${ }^{-1} \mathrm{~h}^{-1}$. More recently, Bockstahler \& Coats (1993a, b) used the protargol silver-staining technique to recognize nanociliates ingested by the mixotrophic dinoflagellates Gymnodinium sanguineum, Gyrodinium uncatenum, and Ceratium furca and calculated in situ grazing rates for $G$. sanguineum $\left(\leq 0.06\right.$ prey $\left.h^{-1}\right)$ from estimates of food vacuole content and digestion rate. However, they were unable to identify the contents of many food vacuoles (up to $81 \%$ in C. furca) using protargol staining.

Evidence from fluorescent microscopy suggests that photosynthetic dinoflagellates may ingest a variety of prey in addition to those seen with the protargol tech- 
nique. For example, yellow-fluorescent inclusions, which could be digestive vacuoles containing phycoerythrin, have been observed in Ceratium spp. (Chang \& Carpenter 1994). Without experimental data or better characterization of inclusions using cytological staining, electron microscopy, etc, it is impossible to determine if these inclusion bodies are autophagic vacuoles, accumulation bodies, endosymbionts, or the remains of ingested prey (Spector 1984, Chang \& Carpenter 1994, Gordon et al. 1994, Zhou \& Fritz 1994).

Visually detected surrogate prey, including dye and starch particles, fluorescent microspheres, and fluorescently labeled, heat-killed bacteria (FLB) and algae (FLA) have been used to investigate feeding behaviors and to measure ingestion rates of planktonic protists (Bird \& Kalff 1987, Sherr et al. 1987, Rublee \& Gallegos 1989, Sherr \& Sherr 1993, Landry 1994). However, use of surrogates to detect feeding may not be appropriate for all types of protistan grazcrs, as some species discriminate against or will not readily ingest inert particles, including heat-killed cells (Stoecker 1988, Verity 1991, Landry 1994). Phagotrophy by certain taxa may go undetected using inert, surrogate prey, and species that do ingest inert particles may exhibit atypical ingestion rates compared to consumption of live prey (Nygaard \& Hessen 1990, Putt 1991). Discrimination among particles appears to be greater in protists that ingest relatively large particles, compared to their own size, than in protists that consume many small particles at one time (Stoecker 1988, Verity 1991). Dinoflagellates usually prey on cells close to their own size (Hansen et al. 1994), thus use of inert surrogates to detect dinoflagellate grazing may be particularly inappropriate.

Live, fluorescently stained prey represent a desirable alternative to inert particles when attempting to detect feeding, determine feeding preferences, and measure ingestion rates of dinoflagellates and other protistan grazers. For example, hydroethidine has been used as a vital stain for protists in single species tracer studies of ciliate grazing (Putt 1991). However, hydroethidine has not come into common use as a tracer in ecological studies due to its toxicity and red fluorescence, which is similar to that of chlorophyll (Putt 1991).

To experimentally investigate feeding by photosynthetic dinoflagellates, we developed new protocols for the use of live protistan prey as tracers of ingestion. We report 2 techniques for studying dinoflagellate feeding in culture and natural assemblages: addition of vitally stained protists and addition of phycoerythrincontaining cryptophytes. CMFDA (5-chloromethylfluorescein diacetate) was used to label prey, because it is a vital stain that has a bright green fluorescence (Haugland 1994), easily distinguished from the red chlorophyll fluorescence found in most photosynthetic cells. Furthermore, CMFDA is metabolized to an aldehyde-fixable, thiol-conjugated product that is trapped within cells for at least $72 \mathrm{~h}$. While this dye carries a warning as a possible human hazard, its toxicity appears to be extremely low, as CMFDA has been used to stain living cells for several generations (Haugland 1994). The cryptophytes Pyrenomonas salina and Cryptomonas sp. were chosen as unstained prey because they contain phycoerythrin which is yellow or orange fluorescent and thus, these phytoflagellates are distinguishable from non-phycoerythrin containing cells. Both genera are common components of the nanoplankton in estuarine and coastal waters in which dinoflagellates are also abundant (McCarthy et al. 1974, Marshall 1980, 1994).

\section{MATERIALS AND METHODS}

Protist cultures. Isochrysis galbana (strain Iso = CCMP1323, $4 \mu \mathrm{m}$ ), Pyrenomonas salina (= Chroomonas salina; strain $3 \mathrm{C}=$ CCMP1319, 6 to $9 \mu \mathrm{m})$, and the dinoflagellate Heterocapsa triquetra (strain HT984 $=$ CCMP448, 14 to $20 \mu \mathrm{m}$ ) were obtained from the Provasoli-Guillard Center for the Culture of Marine Phytoplankton, West Boothbay Harbor, ME, USA. Cryptomonas sp. (strain HP9001, 4 to $7 \mu \mathrm{m}$ ) and a small centric diatom (strain L, 3 to $4 \mu \mathrm{m}$ ) were obtained from Dr T. Kana at Horn Point Environmental Laboratory (HPEL, Cambridge, MD, USA). Gymnodinium sanguineum (strain Gymno, 40 to $60 \mu \mathrm{m}$ ) and Gyrodinium estuariale (strain GE, 10 to $15 \mu \mathrm{m}$ ), and the oligotrichous ciliate Strobilidium sp. (strain Stro, 16 to $20 \mu \mathrm{m}$ ) were isolated from the mesohaline portion of Chesapeake Bay (USA) by D.W.C. and A.L. All cultures were maintained at HPEL and grown at $20^{\circ} \mathrm{C}$. Algal species were cultured in $\mathrm{f} / 2$ medium on a 12:12 h light:dark cycle under cool white fluorescent bulbs $\left(150 \mu \mathrm{E} \mathrm{m} \mathrm{m}^{-2}\right.$ $\mathrm{s}^{-1}$ ), with silicate added to the medium for growth of the centric diatom. Strobilidium $\mathrm{sp}$. was cultured in $\mathrm{f} / 2$ medium on a 14:10 h light:dark cycle at about $50 \mu \mathrm{E}$ $\mathrm{m}^{-2} \mathrm{~s}^{-1}$, with $I$. galbana added as the food source.

Staining and fixation. To determine the optimal concentration of CMFDA (Molecular Probes ${ }^{3}$ ) and appropriate staining time for labeling potential prey, we exposed log-growth cultures of Isochrysis galbana, Pyrenomonas salina, Heterocapsa triquetra, a centric diatom, and the ciliate Strobilidium sp. to $0.1,1.0$, and $3.0 \mu \mathrm{M}$ CMFDA for $0.5,1.0$, and $3.0 \mathrm{~h}$. Working solutions of CMFDA were obtained by diluting a $100 \mu \mathrm{M}$ stock solution prepared in dimethyl sulfoxide using $f / 2$ medium, and staining was always carried out in the dark to minimize the effect of light on the chemical reaction. Samples were preserved with cold $\left(4^{\circ} \mathrm{C}\right)$ 
glutaraldehyde at a final concentration of $1 \%$ and examined as described below.

The ability to detect CMFDA-stained prey inside of dinoflagellate food vacuoles was examined following fixation with $4^{\circ} \mathrm{C}$ glutaraldehyde and buffered (hexamethylamine) formaldehyde, separately. A $1 \mathrm{ml}$ volume of Strobilidium sp. culture was stained with $1 \mu \mathrm{M}$ of CMFDA for $1 \mathrm{~h}$ and then added as prey to $100 \mathrm{ml}$ of Gymnodinium sanguineum culture. The mixture was incubated at $21^{\circ} \mathrm{C}$ and $100 \mu \mathrm{E} \mathrm{m}^{-2} \mathrm{~s}^{-1}$, with $10 \mathrm{ml} \mathrm{sub-}$ samples preserved after $3 \mathrm{~h}$ at final concentrations of $0.5,1.0$, or $2.0 \%$ for both fixatives.

Aliquats (2 ml) of preserved samples were gently concentrated by filtration onto $2 \mu \mathrm{m}$ pore size black membrane filters (Poretics Corporation $\left.{ }^{(}\right)$, Each filter was mounted on a glass slide using immersion oil (Resolve ${ }^{\circledR}$, low viscosity, low fluorescence), an additional drop of oil was then added to the top of the filter, and the preparation was capped with a coverslip. Slides were stored frozen at $-20^{\circ} \mathrm{C}$ and were subsequently examined with epifluorescent microscopy (Zeiss filter set 487709: BP450-490 exciter filter, FT510 dichromatic beam splitter, and LP520 barrier filter).

Feeding experiments with CMFDA-labeled protists. The applicability of the CMFDA technique to dinoflagellate feeding studies was tested using Isochrysis galbana as prey and Gyrodinium estuariale as the predator. I. Galbana culture $\left(1 \times 10^{7} \mathrm{ml}^{-1}\right)$ was stained with $1 \mu \mathrm{M}$ CMFDA for $1 \mathrm{~h}$, and 0 to $2.5 \mathrm{ml}$ was then added to a duplicate series of flasks containing $100 \mathrm{ml}$ of exponentially growing $G$. estuariale culture $(3 \times$ $10^{3} \mathrm{ml}^{-1}$ ) to achieve prey densities ranging from 0 to $2.5 \times 10^{5}$ cells $\mathrm{ml}^{-1}$. Controls for direct uptake of stain by the dinoflagellate consisted of filtrate from stained I. galbana (Acrodisc ${ }^{\ominus}$ syringe filter, $0.2 \mu \mathrm{m}$ pore size) added to a parallel series of duplicate $G$. estuariale cultures. Treatments and controls were incubated for $4 \mathrm{~h}$ at $22^{\circ} \mathrm{C}$ and $150 \mu \mathrm{E} \mathrm{m} \mathrm{m}^{-1}$. At the end of the incubation, subsamples were fixed, filtered, and slides examined using epifluorescence microscopy. The first $100 \mathrm{G}$. estuariale encountered on each slide were examined for the presence or absence of ingested prey, determined as green-fluorescent inclusions (GFI).

Shipboard experiments to determine the feasibility of using CMFDA-labeled prey to detect grazing by natural assemblages of mixotrophic dinoflagellates were done in July 1994. Water samples were collected with Niskin bottles from the surface and the subsurface chlorophyll maximum or pycnocline at stations along the axis of Chesapeake Bay (Stn 813: $38^{\circ} 13^{\prime} \mathrm{N}_{\text {, }}$ $76^{\circ} 15^{\prime} \mathrm{W}_{;}$Stn 818: 38 $18^{\prime} \mathrm{N}$, $76^{\circ} 17^{\prime} \mathrm{W}$; Stn BM4: $38^{\circ} 25^{\prime} \mathrm{N}, \quad 76^{\circ} 23^{\prime} \mathrm{W}$; Stn BM7: $38^{\circ} 25^{\prime} \mathrm{N}, 76^{\circ} 20^{\prime} \mathrm{W}$; Stn 744: $37^{\circ} 44^{\prime} \mathrm{N}, \quad 76^{\circ} 11^{\prime} \mathrm{W} ; \quad \operatorname{Stn} 724: 37^{\circ} 24^{\prime} \mathrm{N}$, $\left.76^{\circ} 05^{\prime} \mathrm{W}\right)$. Water samples were examined immediately after collection for the presence $\left(>1\right.$ cell $\left.\mathrm{ml}^{-1}\right)$ of Cer- atium furca, Gymnodinium sanguineum, Gyrodinium estuariale, Peridinium brevipes or Prorocentrum minimum. We focused on these species because they commonly occur in the Bay during summer (Marshall 1980, 1994), and because they are either known to be mixotrophic (Bockstahler \& Coats 1993b) or have been observed to contain inclusion bodies that might be food vacuoles (Stoecker pers. obs.)

Cultures of potential prey were stained with $1 \mu \mathrm{M}$ CMFDA for 45 to $60 \mathrm{~min}$, and then 1 to $1.8 \mathrm{ml}$ of labeled prey was added separately to $100 \mathrm{ml}$ of sample to achieve target prey densities of $2 \times 10^{4} \mathrm{ml}^{-1}$ for Isochrysis galbana, $2 \times 10^{2} \mathrm{ml}^{-1}$ for Strobilidium sp., and $2 \times 10^{4} \mathrm{ml}^{-1}$ for the diatom. A $0.2 \mu \mathrm{m}$ syringe filter $\left(\right.$ Acrodisc $^{(B)}$ ) was used to obtain cell-free filtrate of CMFDA-labeled $I$. galbana culture, and a volume of this filtrate, equivalent to that of introduced prey, was added to $100 \mathrm{ml}$ of sample as the control. Control and treatments were incubated in $250 \mathrm{ml}$ polycarbonate flasks in the dark at near in situ temperature $(20$ to $23^{\circ} \mathrm{C}$ ) for $4 \mathrm{~h}$, with all experiments started within 1 to $2 \mathrm{~h}$ of sample collection. At the end of the incubation, samples were fixed with cold glutaraldehyde at $1 \%$ final concentration and stored at $4{ }^{\circ} \mathrm{C}$.

Fifty $\mathrm{ml}$ of each sample was settled in an Utermöhl chamber and examined at $400 \times$ using an inverted microscope equipped for transmitted light and epifluorescence microscopy (Hasle 1978). At least 30 cells of dinoflagellate species of interest were examined per sample and scored for presence or absence of GFI. The likelihood-ratio chi-square (G2) statistic (SAS Institute 1990) was used to test for differences in the frequency of GFI between treatments and controls.

Feeding experiments with cryptophytes. Three sets of shipboard experiments were also conducted to determine if addition of cryptophytes to natural assemblages could be used to detect grazing by photosynthetic dinoflagellates. The first set was done in July 1994 using the same water samples as in the CMFDA experiments described above. One to $2 \mathrm{ml}$ of Pyrenomonas salina culture was added to $100 \mathrm{ml}$ of sample to achieve an added prey density of approximately $2 \times$ $10^{4} \mathrm{ml}^{-1}$. Controls consisted of sample without the addition of prey. Incubation, fixation and statistical analyses were the same as reported above for CMFDA experiments.

A second set experiment was carried out in May 1995 using surface water from Stn 858 that contained Gyrodinium estuariale at about $40 \mathrm{ml}^{-1}$. Treatments were: without addition of prey (Cryptomonas sp.), and with prey added at a calculated density of 1000, 2000, 3000, 4000 , and 5000 cells $\mathrm{ml}^{-1}$. The experiment was run in duplicate with $100 \mathrm{ml}$ samples placed in $250 \mathrm{ml}$ polycarbonate bottles and incubated in a circulating, estuarine water bath at surface light intensity $\left(1490 \mu \mathrm{E} \mathrm{m} \mathrm{m}^{-2}\right.$ 
$\left.\mathrm{s}^{-1}\right)$ and temperature $\left(16.5\right.$ to $\left.17.0^{\circ} \mathrm{C}\right)$. After $4 \mathrm{~h}$ of incubation, samples were fixed in $1 \%$ final concentration of glutaraldehyde, and $5 \mathrm{ml}$ aliquots were filtered and pracessed for epifluorescent microscopy as described above for laboratory studies. The presence of yellow or orange fluorescent inclusions (OFI) was recorded for the first $100 \mathrm{G}$. estuariale encountered on each slide.

A final set of experiments was done during summer 1995 by adding Cryptomonas sp. to plankton assemblages containing Prorocentrum minimum at $>100 \mathrm{ml}^{-1}$. These experiments were similar to those previously described for additions of Pyrenomonas salina, except that incubations were in an on-deck incubator at near in situ light intensities $\left(64 \% I_{0}\right)$ and temperatures,

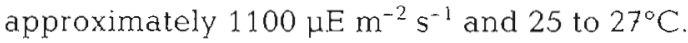

\section{RESULTS}

\section{Experiments with CMFDA-labeled prey}

Potential prey used in this study exhibited different staining properties when exposed to CMFDA. Isochrysis galbana, Heterocapsa triquetra, and Strobilidium sp. stained brightly within $1 \mathrm{~h}$ at CMFDA concentrations $\geq 1 \mathrm{mM}$. Bright staining of diatom strain ' $\mathrm{L}$ ' was only obtained after cells were exposed to $3 \mu \mathrm{M}$ CMFDA for $\geq 1 \mathrm{~h}$. The cryptophyte Pyrenomonas salina stained poorly even at a stain concentration of $3 \mu \mathrm{M}$ and a staining time of $3 \mathrm{~h}$.

No background staining was observed in fresh samples at CMFDA concentrations $\leq 1 \mu \mathrm{M}$; however, increased background fluorescence was detected following storage of samples at $4^{\circ} \mathrm{C}$ for more than $2 \mathrm{mo}$. Use of 2 to $3 \mu \mathrm{M}$ CMFDA also resulted in background staining and may cause additional problems due to: (1) possible toxic effects from increased dimethyl sulfoxide (DMSO) concentrations, and (2) direct staining of grazers from greater carry-over of free CMFDA into experimental incubations. However, no direct staining of grazers or toxic effects were apparent at carry-over concentrations of CMFDA $(\leq 0.025 \mu \mathrm{M})$ and DMSO $(0.025 \% \mathrm{v} / \mathrm{v})$ present in laboratory and field studies reported here. Furthermore, CMFDA-stained prey appeared to have normal locomotory patterns and continued to divide

Strobilidium sp. and Isochrysis galbana stained with $1 \mu \mathrm{M}$ CMFDA for $1 \mathrm{~h}$ were easily detected within food vacuoles of Gymnodinium sanguineum fixed with $1 \%$ or $2 \%$ glutaraldehyde. However, fixation in $0.5 \%$ glutaraldehyde resulted in poor preservation of $G$. sanguineum and diminished visualization of ingested prey. Glutaraldehyde fixation also produced brighter fluorescence of CMFDA and chlorophyll than preservation in comparable concentrations of buffered form- aldehyde. Furthermore, when glutaraldehyde fixed samples were filtered, processed as slide preparations, and stored at $4^{\circ} \mathrm{C}$, CMFDA fluorescence remained bright, with little or no development of background staining for at least $3 \mathrm{mo}$.

In the laboratory, CMFDA-stained Isochrysis galbana ingested by cultured Gyrodinium estuariale were readily visible and could be enumerated as green fluorescent inclusions (Fig. 1B). The percentage of cells containing green fluorescent inclusions (GFI) appeared to increase hyperbolically with prey density (Fig. 2); however, data for low prey densities were insufficient to clearly define this relationship. G. estuariale from controls lacked CMFDA fluorescent inclusions, even at the highest carry-over concentration of stain $(0.025 \mu \mathrm{M})$

GFI were also easily detected in Ceratium furca (Fig. 1E), Gymnodinium sanguineum, and Prorocentrum minimum following incubation of field populations in the presence of CMFDA-labeled prey. In all 3 species, the percentage of cells with GFI was often significantly higher in treatments spiked with a mixture of CMFDA-labeled Strobilidium sp. and Isochrysis galbana than in controls containing labeled-prey filtrate (Table 1). Addition of stained I. galbana often resulted in higher prevalence of GFI in C. furca and P. minimum, relative to controls; however, differences were not statistically significant (Table 1). In most experiments with addition of labeled diatoms, the frequency of dinoflagellates containing GFI was less than in CMFDA controls, providing no evidence for ingestion of the diatom.

\section{Experiments with added cryptophytes}

Orange to yellow-orange fluorescent inclusions (OFI), presumably resulting from the ingestion of phycoerythrin-containing prey, were commonly observed in Chesapeake Bay populations of Gyrodinium estuariale, Prorocentrum minimum, Ceratium furca, and Peridinium brevipes (Fig. 1A, C, D). In many instances, the prevalence of OFI in these species increased following the addition of phycoerythrin-containing cryptophytes to natural plankton assemblages. For example, addition of Cryptomonas sp. to plankton samples containing $G$. estuariale resulted in a curvilinear increase in the prevalence of OFI from $13 \%$, at ambient cryptophyte densities of 600 cells m.l $^{-1}$, to over $60 \%$ at an addition of $5 \times 10^{3}$ Cryptomonas sp. ml $l^{-1}$ (Fig. 3).

Upward shifts in the prevalence of OF $\downarrow$ following the addition of cryptophytes were also detected in natural assemblages of Gymnodinium sanguineum, Prorocentrum minimum, and Peridinium brevipes ${ }_{i}$ however, the tendency for increased occurrence of OFI appeared to differ among mixotroph species 

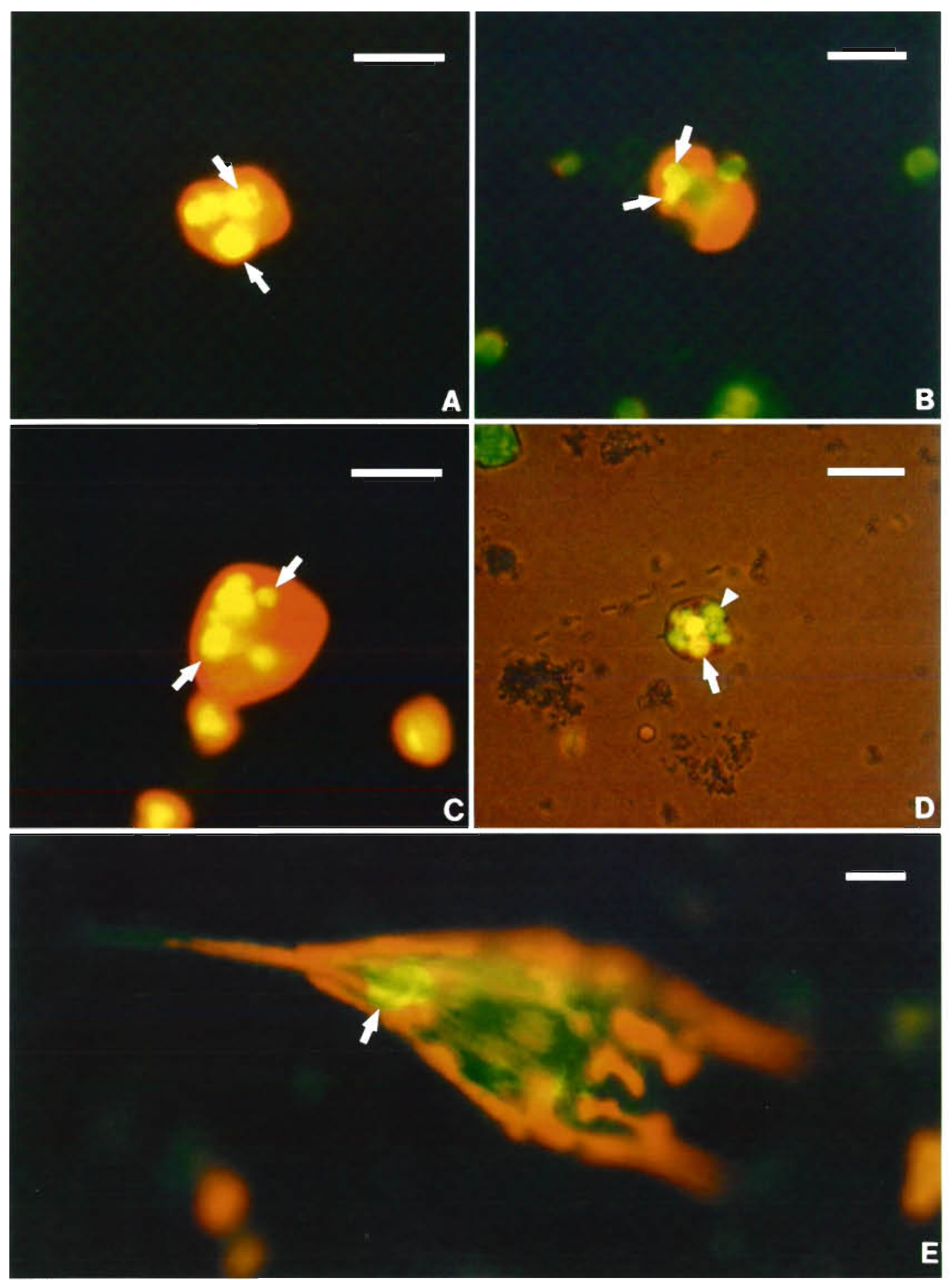

Fig. 1. Epifluorescent micrographs of mixotrophic dinoflagellates with ingested cryptophytes or CMFDA-labeled protists. (A) Gyrodinium estuariale with 3 ingested Cryptomonas sp. (arrows); scale bar $=10 \mu \mathrm{m}$. (B) G. estuariale with ingested CMFDAlabeled Isochrysis galbana (arrows); scale bar $=10 \mu \mathrm{m}$. (C) Prorocentrum minimum with ingested Cryptomonas sp. (arrows); scale bar $=10 \mu \mathrm{m}$. (D) Peridinium brevipes with ingested cryptophytes (arrow) and CMFDA-labeled Strobilidium sp. (arrow head); scale bar $=30 \mu \mathrm{m}$. (E) Ceratium furca with an ingested Strobilidium sp. (arrow); scale bar $=10 \mu \mathrm{m}$ 


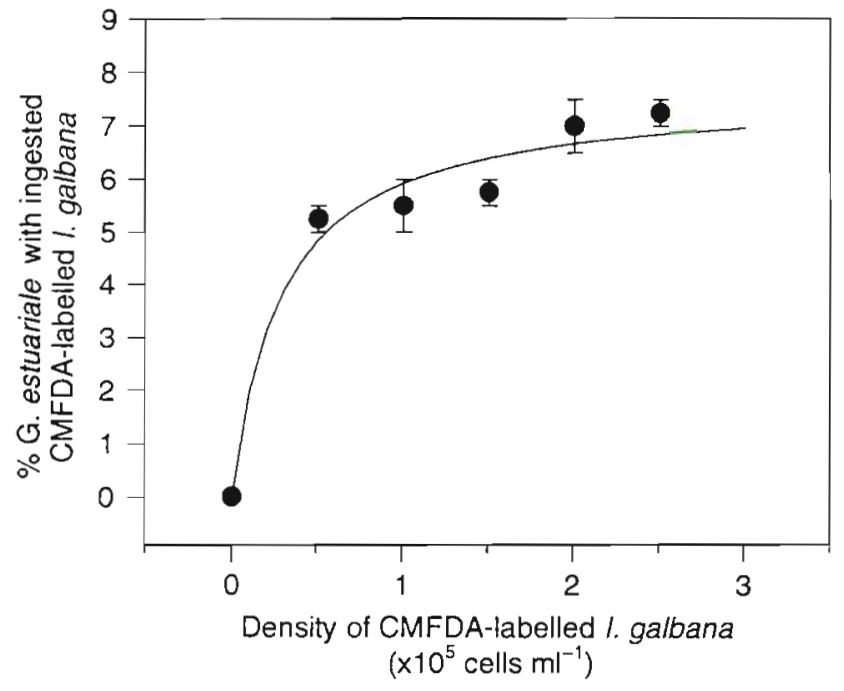

Fig. 2. Laboratory experiment showing the effect of prey density on the percentage of Gyrodinium estuariale containing CMFDA-labeled Isochrysis galbana: incubation time $=4 \mathrm{~h}$ (bars represent standard error of mean; $n=2$ ). Curve fitted by hyperbolic function

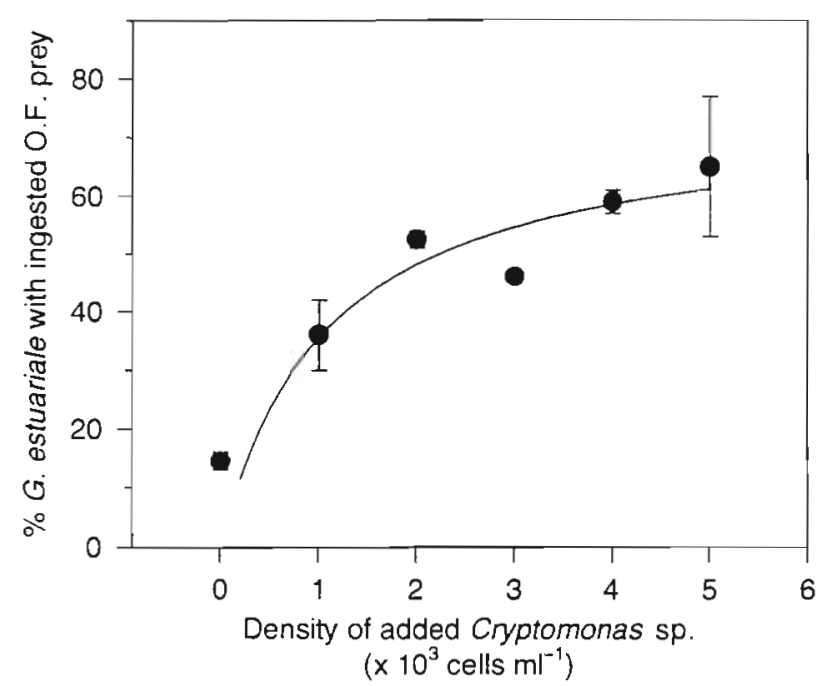

Fig. 3. Percentage of Gyrodinium estuariale containing orange fluorescent inclusions relative to density of Cryptomonas sp. added to surface water collected at Stn 858 during a cruise in May 1995 (bars = standard error of mean; $n=2$ ). Curve fitted by hyperbolic function

Table 1. Addition of CMFDA-labeled prey to natural assemblages from Chesapeake Bay, USA, July 1994. Stro: Strobilidium sp., Iso: Isochrysis galbana; L: centric diatom. Frequencies of dinoflagellate cells with green fluorescent inclusions (GFI) in treatments were compared to frequencies in CMFDA controls using likelihood ratio chi-squared (G2) tests. ns: not significant; $\cdots p<0.01$ Surface water was used in all experiments except at Stn 818 , where water from $6 \mathrm{~m}$ depth was incubated

\begin{tabular}{|c|c|c|c|c|c|}
\hline Dinoflagellate species & Stn & Treatment & No. of cells observed & $\%$ of cells with GFI & $\mathrm{p}$ \\
\hline Ceratium furca & 744 & $\begin{array}{l}\text { CMFDA control } \\
+ \text { Stro + Iso } \\
+ \text { Iso }\end{array}$ & $\begin{array}{l}49 \\
26 \\
46\end{array}$ & $\begin{array}{r}4 \\
31 \\
7\end{array}$ & $\begin{array}{l}0.001 \cdots \\
0.584 \mathrm{~ns}\end{array}$ \\
\hline Gymnodinium sanguineum & 818 & $\begin{array}{l}\text { CMFDA control } \\
+ \text { Iso } \\
+\mathrm{L} \\
\text { CMFDA control } \\
+ \text { Stro + Iso } \\
+\mathrm{L}\end{array}$ & $\begin{array}{r}39 \\
44 \\
60 \\
102 \\
27 \\
35\end{array}$ & $\begin{array}{r}15 \\
11 \\
18 \\
12 \\
44 \\
9\end{array}$ & $\begin{array}{l}0.590 \mathrm{~ns} \\
0.702 \mathrm{~ns} \\
0.000 \cdots \\
0.593 \mathrm{~ns}\end{array}$ \\
\hline Prorocentrum minimum & $\begin{array}{l}\text { BM4 } \\
\text { BM7 } \\
818\end{array}$ & $\begin{array}{l}\text { CMFDA control } \\
+ \text { Stro + Iso } \\
+ \text { Iso } \\
\text { + L } \\
\text { CMFDA control } \\
+ \text { Iso } \\
\text { + L } \\
\text { CMFDA control } \\
\text { + Stro + Iso } \\
\text { + Iso } \\
\text { + L } \\
\text { CMFDA control } \\
\text { + Stro+ Iso } \\
\text { + Iso } \\
\text { CMFDA control } \\
\text { + Stro+ Iso } \\
\text { + Iso } \\
\text { + L }\end{array}$ & $\begin{array}{r}116 \\
110 \\
101 \\
110 \\
104 \\
114 \\
115 \\
119 \\
108 \\
105 \\
117 \\
104 \\
109 \\
105 \\
101 \\
100 \\
26 \\
82\end{array}$ & $\begin{array}{r}0 \\
0 \\
2 \\
0 \\
0 \\
1 \\
1 \\
0 \\
25 \\
2 \\
0 \\
0 \\
25 \\
2 \\
0 \\
13 \\
0 \\
1\end{array}$ & $\begin{array}{c}-\mathrm{ns} \\
0.079 \mathrm{~ns} \\
-\quad \mathrm{ns} \\
0.254 \mathrm{~ns} \\
0.256 \mathrm{~ns} \\
0.000 \cdots \\
0.081 \mathrm{~ns} \\
-\quad \mathrm{ns} \\
0.000 \cdots \\
0.096 \mathrm{~ns} \\
0.000 \cdots \\
-\quad \mathrm{ns} \\
0.204 \mathrm{~ns}\end{array}$ \\
\hline Peridinium brevipes & $\mathrm{BM} 4$ & $\begin{array}{l}\text { CMFDA control } \\
+ \text { Stro+ Iso } \\
+ \text { Iso } \\
+ \text { L }\end{array}$ & $\begin{array}{r}158 \\
114 \\
82 \\
112\end{array}$ & $\begin{array}{l}0 \\
0 \\
0 \\
0\end{array}$ & $\begin{array}{ll}- & \mathrm{ns} \\
- & \mathrm{nS} \\
- & \mathrm{nS}\end{array}$ \\
\hline
\end{tabular}


Table 2. Addition of Pyrenomonas salina to natural assemblages from Chesapeake Bay, July 1994. Frequencies of dinoflagellate cells with orange fluorescent inclusions (OFI) in treatment were compared to frequencies in controls using likelihood ratio chisquared $(G 2)$ tests. ns: not significant ${ }_{i} \cdots p<0.01$. Surface water was used in all experiments except at Stn 818 , where water from $6 \mathrm{~m}$ depth was incubated

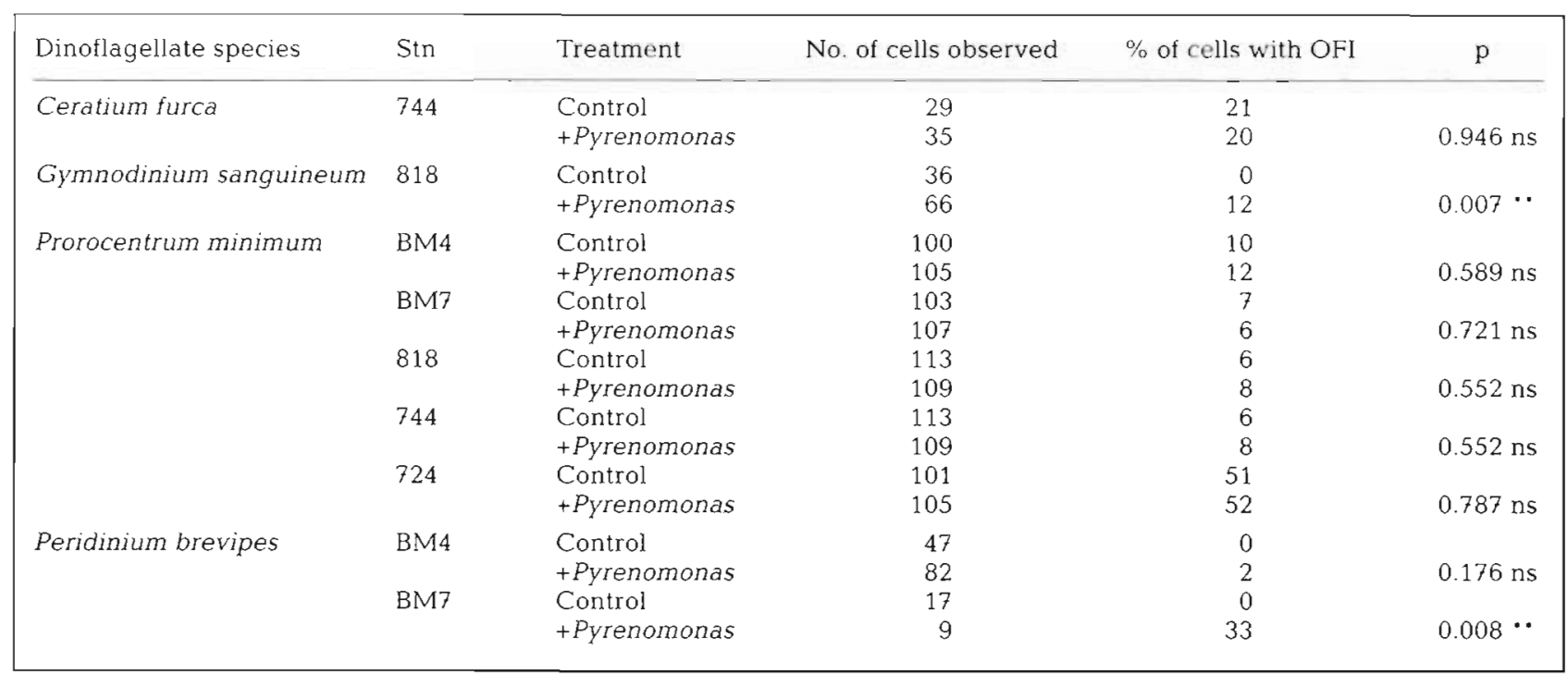

(Tables 2 \& 3). Also, the response may partially depend on the species of cryptophyte added as potential prey. For example, the percentage of $P$. minimum possessing OFI in unamended, control samples was similar in 1994 (Table 2) and 1995 (Table 3), with an overall range of 0 to $51 \%$. Addition of Pyrenomonas salina to treatments on 5 occasions in 1994 resulted in no significant increase in frequency of cells with OFI, even though $P$. minimum from some of those water samples appeared to ingest CMFDA-labeled Strobilidium sp. (cf. Tables 1 \& 2). In contrast, a significant increase in the percentage of $P$ minimum containing OFI following the addition of Cryptomonas sp. was observed in 1 of 3 experiments in 1995.

Table 3. Addition of Cryptomonas sp. to natural assemblages from Chesapeake Bay, July and August 1995. Frequency of yellow or orange fluorescent inclusions (OFI) in Prorocentrum minimum in control and treatment compared using likelihood ratio chi-squared (G2) test. ns: not significant; $\cdots p<0.01$. Surface water samples incubated at $64 \%$ surface light intensity $\left(I_{0}\right)$ for $4 \mathrm{~h}$ (July experiments) or $1 \mathrm{~h}$ (August experiment)

\begin{tabular}{|c|c|c|c|c|c|}
\hline Stn & Month & Treatment & No. of cells & $\begin{array}{l}\% \text { with OFI } \\
\text { observed }\end{array}$ & $\mathrm{p}$ \\
\hline 813 & July & $\begin{array}{l}\text { Control } \\
+ \text { Cryptomonas }\end{array}$ & $\begin{array}{l}124 \\
132\end{array}$ & $\begin{array}{l}19 \\
24\end{array}$ & $0.540 \mathrm{~ns}$ \\
\hline 818 & July & $\begin{array}{l}\text { Control } \\
+ \text { Cryptomonas }\end{array}$ & $\begin{array}{l}447 \\
497\end{array}$ & $\begin{array}{l}11 \\
20\end{array}$ & $0.175 \mathrm{~ns}$ \\
\hline 818 & August & $\begin{array}{l}\text { Control } \\
+ \text { Cryptomonas }\end{array}$ & $\begin{array}{l}112 \\
130\end{array}$ & $\begin{array}{c}0 \\
10\end{array}$ & $0.000 \cdots$ \\
\hline
\end{tabular}

\section{DISCUSSION}

CMFDA-staining of live protists and use of phycoerythrin-containing cryptophytes as potential prey are valuable techniques for investigating ingestion of food particles by mixotrophic dinoflagellates. Using a combination of these approaches, we documented feeding by natural assemblages of the photosynthetic dinoflagellates Ceratium furca, Gymnodinium sanguineum, Gyrodinium estuariale, Prorocentrum minimum and Peridinium brevipes from Chesapeake Bay. We also demonstrated ingestion of CMFDA-labeled Isochrysis galbana by laboratory cultures of $G$. estuariale.

Ceratium furca ingested CMFDA-labeled Strobilidium sp. (Table 1) in agreement with earlier observations that this dinoflagellate consumes oligotrichous ciliates (Bockstahler \& Coats 1993b). We also observed orange to yellow-orange fluorescent inclusions (OFI) in $C$. furca from unamended water samples, but the frequency of OFI did not increase following the addition of the cryptophyte Pyrenomonas salina (Table 2). Since $C$. furca consumes ciliates, then OFI observed in this species may be due to ingestion of planktonic ciliates that contain symbiotic cryptophytes (e.g. Mesodinium rubrum; Taylor 1990) or sequestered cryptophyte plastids (e.g. Strombidium spp.; Stoecker et al. 1989). However, data from experi- 
ments using a single cryptophyte species as potential prey are insufficient to exclude the possibility that $C$. furca directly ingests other phycoerythrin-containing members of the phylum.

Feeding by Gymnodinium sanguineum was observed when either CMFDA-labeled Strobilidium sp. or unstained Pyrenomonas salina were added to plankton assemblages (Tables $1 \& 2$ ). That $G$. sanguineum ingested labeled ciliates is not surprising, as it too is known to consume small oligotrichous species (Bockstahler \& Coats 1993a). However, uptake of P. salina by this mixotroph may represent direct utilization of flagellates, or may reflect consumption of ciliates in the natural assemblage that ingested the added cryptophytes (Stoecker et al. 1989). Green fluorescent inclusions (GFI) similar to CMFDA-labeled prey were also observed in G. sanguineum from unamended samples and were present in over $10 \%$ of individuals in CMFDA controls. Since dinoflagellate nuclei have been observed in the food vacuoles of $G$. sanguineum (Bockstahler \& Coats 1993b), it seems possible that some GFI observed in cells from unamended and control samples were due to ingestion of greenfluorescent heterotrophic dinoflagellates (Shapiro et al. 1989, Carpenter et al. 1991), which are common in Chesapeake Bay (pers. obs.).

Gyrodinium estuariale often had OFI in natural samples from Chesapeake Bay and readily ingested added Cryptomonas sp. in the shipboard experiment. In the laboratory, $G$. estuariale also ingested the small prymnesiophyte Isochrysis galbana. This is the first report of feeding in this dinoflagellate species.

In some, but not all, of our shipboard experiments, feeding was detected in Prorocentrum minimum. There are no previous reports of feeding by this species, although it is common in temperate, estuarine, and coastal waters. Both the small Strobilidium sp. and one of the cryptophytes, Cryptomonas sp., were ingested by $P$. minimumi however, the other cryptophyte, Pyrenomonas salina, was not utilized even though it is intermediate in size between Cryptomonas sp. and the Strobilidium $\mathrm{sp}$.

We frequently observed OFI in Peridinium brevipes in samples from Chesapeake Bay. Our experimental data indicate that this species ran ingest Pyrenomonas salina and thus it seems likely that the OFI observed in unamended samples are due to the ingestion of cryptophytes. However, ingestion of ciliates containing cryptophyte plastids is also a possible source of OFI.

For most of the dinoflagellate species in our experiments, incidence of feeding was quite variable. For example, with Prorocentrum minimum, significant feeding was observed in only 3 out of the 5 stations at which experiments were run. A variety of factors, besides prey availability, have been reported to control feeding in mixotrophic flagellates, including light and the availability of inorganic nutrients (Boraas et al 1988, Porter 1988, Sanders 1991, Keller et al. 1994 Arenovski et al. 1995, Jones et al. 1995). Given the spatial and temporal variability in light attenuation and inorganic nutrient availability in Chesapeake Bay (Fisher et al. 1992, Glibert et al. 1995), the variability in feeding response is perhaps not surprising.

The 2 methods we used to detect feeding in photosynthetic dinoflagellates have advantages and disadvantages. Both techniques are prey-specific, but rely on the addition of cultured prey to experimental incubations and thus involve elevation of prey densities. Added prey probably outnumbered natural prey in most of our experiments. In short-term incubations, cleptochloroplastidy (cytoplasmic sequestration of prey chloroplasts; Schnepf \& Elbrächter 1992) may not be distinguishable from ingestion and digestion of prey. These techriques have the advantage of utilizing live, motile prey rather than inert particles, such as microspheres or heat-killed prey. They are also preferable to the hydroethidine technique in that fluorescence microscopy can be used to detect prey in the presence of chlorophyll and that the additions are low in toxicity or non-toxic to predators and prey.

The CMFDA technique has an advantage over the addition of cryptophytes in that a variety of prey can be used including photosynthetic and heterotrophic protists. Some specific disadvantages of this technique are: (1) not all protists are readily stained, (2) a control needs to be run for the direct uptake of stain by the grazers (the CMFDA control), (3) the green fluorescence of CMFDA might be confused with the green autofluorescence of some unstained prey (e.g. some heterotrophic dinoflagellates), and (4) CMFDA fluorescence fades rapidly in the light.

The addition of cryptophytes has an advantage over CMFDA in that the prey do not need to be manipulated prior to use. Another advantage is that phycoerythrin fluorescence is more stable than that of CMFDA. Thus, with cryptophyte additions, feeding experiments can be run at higher irradiances. Cryptophyte fluorescence also fades less rapidly than CMFDA fluorescence during microscopy. The disadvantages of cryptophyte additions are: (1) phycoerythrin is also found in cyanobacteria, some ciliates and some dinoflagellates (Taylor 1990, Schnepf \& Elbrächter 1992), thus, there is the potential for confusing ingestion of cryptophytes with ingestion of other prey types, (2) naturally occurring cryptophytes (and other cells with phycoerythrin.) can lead to high backgrounds of OFI in controls and may make changes in prevalence of OFJ resulting from addition of prey difficult to detect, and (3) it is limited in application to a few, very specific prey taxa. 
The addition of CMFDA-labeled prey and of phycoerythrin-containing prey are complementary techniques. With the use of proper controls, they can be used to detect ingestion of a variety of protistan prey by natural assemblages of dinoflagellates and to quantify feeding by mixotrophs in laboratory studies. These techniques should also be generally applicable to species-specific feeding studies with other phagotrophic protists and with micro-metazoa

Acknowledgements. We thank the Captaun and crew of the RV 'Cape Henlopen' for ship operation and on-deck assistance, and Daniel E. Gustafson for technical help. This research was supported by NSF grant OCE931772 awarded to D.W.C. and D.K.S., and a HPEL graduate student research grant awarded to A.L.

\section{LITERATURE CITED}

Arenovski AL, Lim EL, Caron DA (1995) Mixotrophic nanoplankton in oligotrophic surface waters of the Sargasso Sea may employ phagotrophy to obtaın major nutrients. J Plankton Res 17:801-820

Bird DF, Kalff J (1987) Algal phagotrophy: regulating factors and importance relative to photosynthesis in Dinobryon (Chrysophyceae). Limnol Oceanogr 32:277-284

Bockstahler KR, Coats DW (1993a) Grazing of the mixotrophic dinoflagellate Gymnodinım sanguineum on ciliate populations of Chesapeake Bay. Mar Biol 116: $477-487$

Bockstahler KR, Coats DW (1993b) Spatial and temporal aspects of mixotrophy in Chesapeake Bay dinoflagellates. J Euk Microbiol 40:49-60

Boraas M, Estep KW, Johnson PW, Sieburth JM (1988) Phagotrophic phototrophs: the ecological significance of mixotrophy. J Protozool 35:249-252

Carpenter EJ, Chang J, Shapiro LP (1991) Green and blue fluorescing dinoflagellates in Bahamian waters. Mar Brol 108:145-149

Chang J, Carpenter EJ (1994) Inclusion bodies in several species of Ceratium Schrank (Dinophyceae) from the Caribbean Sea examined with DNA-specific staining. J Plankton Res 16:197-202

Fisher TR, Peele ER, Ammerman JW, Harding LW Jr (1992) Nutrient limitation of phytoplankton in Chesapeake Bay. Mar Ecol Prog Ser 82:51-63

Glibert PM, Conley DJ, Fisher TR, Harding LW Jr (1995) Dynamics of the 1990 winter/spring bloom in Chesapeake Bay. Mar Ecol Prog Ser 122:27-43

Gordon N, Angel DL, Neori A, Kress N, Kimor B (1994) Heterotrophic dinoflagellates with symbiotic cyanobacteria and nitrogen limitation in the Gulf of Aqaba. Mar Ecol Prog Ser 107:83-88

Hansen B, Bjernsen PK, Hansen PJ (1994) The size ratio between planktonic predators and their prey. Limnol Oceanogr 39:395-403

Hasle GR (1978) Settling: the inverted microscope method. In: Sournia A (ed) Monographs on oceanographic methodology, Vol 6, Phytoplankton manual. UNESCO, Paris, p $88-96$

Haugland RP (1994) Fluorescent dyes for assessing vital cell functions. In: Haugland RP (ed) Handbook of fluorescent probes and research chemucals, 5th edn. Molecular Probes, Inc, Eugene, OR, USA, p 172-180

Jones HLJ, Durjun P, Leadbeater BSC, Green JC (1995) The relationship between photoacclimation and phagotrophy with respect to chlorophyll a, carbon and nitrogen content, and cell size of Chrysochromulina brevifilum (Prymnesiophyceae). Phycologia 34:128-134

Keller MD. Shapiro LP, Haugen EM, Cucci TL. Sherr EB (1994) Phagotrophy of fluorescently labeled bactena by an oceanic phytoplankter Microb Ecol 28:39-52

Landry MR (1994) Methods and controls tor measuring the grazing impact of planktonic protists. Mar Microb Food Webs 8:37-57

Marshall HG (1980) Seasonal phytoplankton composition in the lower Chesapeake Bay and Old Plantation Creek. Cape Charles, Virginia. Estuaries 3:207-216

Marshall HG (1994) Chesapeake Bay phytoplankton: 1. Composition. Proc Biol Soc Wash 107:573-585

MCCarthy JJ, Taylor WR, Loftus ME (1974) Significance of nanoplankton in the Chesapeake Bay estuary and problems associated with the measurement of nanoplankton productivity. Mar Biol 24:7-16

Nygaard K, Hessen DO (1990) Use of ${ }^{14} \mathrm{C}$-protein-labeled bacteria for estimating clearance rates by heterotrophic and mixotrophic flagellates. Mar Ecol Prog Ser 68:7-14

Porter KC (1988) Phagotrophu phytoflagellates in microbial food webs. Hydrobiologia 159:89-97

Putt M (1991) Development and evaluation of tracer particles for use in microzooplankton herbivory studies. Mar Ecol Prog Ser 77:27-37

Rublee PA, Gallegos CL (1989) Use of fluorescently labeled algae (ГLA) to estimate microzooplankton grazing. Mar Ecol Prog Ser 51:221-227

Sanders WR (1991) Mixotrophic protists in marine and freshwater ecosystems. J Protozool 38:76-81

SAS Institute (1990) SAS ${ }^{\circledR}$ procedures guide. Version 6, 3rd edn. SAS Institute, Inc, Cary, NC

Schnepf EM, Elbrächter M (1992) Nutritional strategies in dinoflagellates. Eur J Protistol 28:3-24

Shapıro LP, Haugen LM. Carpenter EJ (1989) Occurrence and abundance of green-fluorescing dinoflagellates in surface waters of the northwest Atlantic and Northeast Pacific Oceans. J Phycol 25:189-191

Sherr BF. Sherr EB, Fallon RD (1987) Use of monodispersed, fluorescently-labeled bacteria to estimate in situ protozoan bacterivory. Appl Environ Microbiol 53:958-965

Sherr EB, Sherr BF (1993) Protıstan grazing rates via uptake of fluorescently labeled prey. In: Kemp PF, Sherr BF, Sherr EB, Cole JJ (eds) Handbook of methods in aquatic microbial ecology. CRC Press, Inc, Boca Raton, p 695-701

Spector DL (1984) Unusual inclusions. In: Spector DL (ed) Dinoflagellates. Academic Press, Inc, Orlando, p 365-390

Stoecker DK (1988) Are marine planktonic ciliates suspension feeders? J Protozool 35:252-255

Stoecker DK, Silver MW, Michaels AE, Davis LH (1989) Enslavement of algal chloroplasts by four Strombidium spp. (Ciliophora, Oligotrichida). Mar Microb Food Webs 3:79-100

Taylor FJR (1990) Symbiosis in marine protozod. In: Capriulo GM (ed) Ecology of marine protozod. Oxford Univ Press, Oxford, p 323-340

Verity PG (1991) Feeding in planktonic protozoans: evidence for non-random acquisition of prey. J Protozool 38:69-76

Zhou J, Fritz L (1994) The PAS/accumulation bodies in Prorocentrum lima and Prorocentrum maculosum (Dinophycea) are dinoflagellate lysosomes. J Phycol 30:39-44 